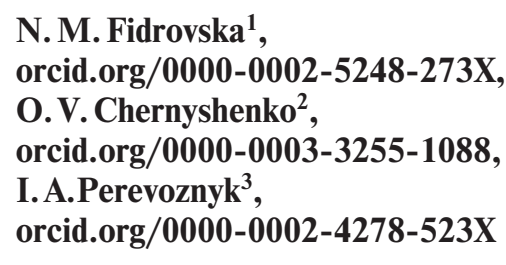

\title{
EXPERIMENTAL STUDY ON AN OVERHEAD CRANE PASSING A RAIL TRACK JOINT
}

Purpose. To confirm the theoretical conclusions that determining the load from the wheel impact with the joint of rails in the metal structures of overhead cranes used in the technological processes at ore mining and processing mills and integrated works and moving along the rail tracks requires that the dynamic magnification factor should take into account the trolley position.

Methodology. To assess the load to which the crane metal structures are exposed the electric strain measurement method using direct bridge circuit was chosen. To calibrate the strain measurement system, the direct method was used, under which calibration is performed directly on the structure on which experimental studies will be carried out in the future.

Findings. It was established that the dynamic magnification factor in the metal structure of the overhead crane had the following values when passing the last rail joints: 1.54 (with the trolley in the middle of the bridge), 2.46 (with the trolley at 0.25 of the crane span from the end beam), 3.33 (with the trolley in the extreme position). So, with the trolley being at a distance of 0.25 of the crane span from the end beam, the dynamic magnification factor is $74 \%$, and with the trolley in the middle of the bridge, it is $46 \%$ of the dynamic magnification factor if the trolley is in its extreme position.

Originality. The scientific novelty consists in the first experimental confirmation of the results obtained in the theoretical studies on the overhead crane passing the joints of the rail track with regard to the crane trolley position, which leads to changes in the stiffness of the main beam in the interval between the trolley and the final beam.

Practical value. The results obtained enable calculations on the crane bridge metal structure during the design and repair of the main and end beams taking into account the value of the dynamic magnification factor, which allows increasing the reliability and durability of the crane metal structure as a whole.

Keywords: overhead crane, rail track joint, dynamic factor, oscillation in the overhead crane beams, impact blow

Introduction. The quality of most crane rails used at the national enterprises is quite low, even critical in some cases. This is primarily due to the service life of cranes, which exceeds the recommended value, as well as the cost of laying new rail tracks. This is especially true for cranes operating in heavy modes (for example, cranes operating at mining and processing mills and integrated works).

The unsatisfactory condition of the rail tracks revealed during the study conducted at many national enterprises brings about significant shock loads that occur during the operation of the crane movement mechanisms. Such shock loads not only result in a significant reduction in the service life of the crane running wheels, but also degrade the strength of the crane metal structure. Shock loads are caused by such local irregularities as potholes or deposit welding, but particularly critical are rail joints. They most significantly affect the level of shock loads and reduce the operating life of the wheels, rails and metal structure of the crane. This is due to the contact force and the shock pulse received by the running wheel from the impact in the area of the wheel and rail, which creates an elastic wave that affects the metal structure of the crane and causes its elastic vibrations.

The crane running wheels passing the joint of the rails produces a severe shock resulting from the crane wheel colliding with the countermoving ledge. Herewith, the vertical speed component of the crane wheel in thousandths of a second increases from zero to maximum values, which are impossible to calculate based merely on the kinematics of the crane wheel passing the joint of the rails. Moreover, the wheel passing the joint of the rails in the opposite direction causes the crane wheel to fall, which, first, makes the vertical speed component increase from zero to some final value, and then instantly decrease to zero.

According to the overhead crane operation rules, mutual displacement of ends of joined rails in plan and heightwise cannot exceed $2 \mathrm{~mm}$, and gaps in joints of rails cannot exceed

(C) Fidrovska N. M., Chernyshenko O.V., Perevoznyk I. A., 2021
$6 \mathrm{~mm}$. Numerous examinations of crane rails conducted by the authors at various industrial enterprises (Turboatom JSC, Svitlo Shakhtaria JSC, Ore-Mining and Processing Mill in Inhulets, TEKhVAHONMASH Research and Production Company LLC) reveal that joints of rails are often in an unsatisfactory condition: gaps as big as $20-30 \mathrm{~mm}$ occur and the difference in height can reach 5-10 $\mathrm{mm}$; sometimes there are potholes $10-12 \mathrm{~mm}$ deep and $30-40 \mathrm{~mm}$ long. The unsatisfactory condition of the rail track finds confirmation in the works by many authors.

Taking into account the actual values of shock loads during design and operation of metal structures and mechanisms of cranes, as well as crane tracks can significantly increase the fail-safe and trouble-free service life of cranes.

Literature review. Many publications of well-known scientists provide analysis of the influence of rail track joints on the dynamic loads occurring during the movement of the crane wheels. The authors who conducted such studies point out that determining the dynamic shock loads of the cranes is a rather difficult task and is not fully defined yet. Creation of high technologies and development of new techniques require the most accurate knowledge of short-term and rapidly changing processes accompanied by emergence of shock waves that can be presented as compressional waves that can cause significant deformation, changes in the crystal lattice and local overheating of wheels and rails.

We will dwell on the latest works. The dynamic impact stress caused by the movement of the crane wheels is quite big and cannot be ignored in crane design [1-3].

Modern development of computer engineering makes enables solving practical problems of dynamics on the basis of more complex calculation schemes and corresponding mathematical models that more accurately simulate the work of machines [4]. Particularly dynamic loads occur in the operation of mechanisms responsible for movement of the cargo carts and the crane.

The work [5] presents dynamic models for mechanisms of movement in wheel and rail wear due to misalignments on 
cranes. The authors determine linear vibrations of the model that describes the cargo and trolley vibrations during the crane movement and evaluate the friction force in the system. The influence of load variability during the effect of the resistance force during the crane movement is evaluated. The dynamic loads in the metal structure of the crane are not considered in the work.

The work [6] offers a definition of dynamic forces in the crane elastic system when passing the joint of rails with the set movement speed. This was solved using a two-mass system taking into account only the bridge compliance. The following assumptions were made: wheels, rails, rail supports, end beams are absolutely rigid and the wheels are simultaneously meeting with the joints. The article obtained the solution which allows determining the dynamic forces that occur in the metal structure of the crane when the running wheel is passing the joint of the rail taking into account the height of the joint and the geometric parameters of the wheel.

The work [7] presents the impact of the rail track joint on the dynamic loads that will occur in the crane beams during the movement of the running wheels. The shock in the zone of wheel-rail contact causes a contact force of elastic deformation of the wheel-rail system. The shock impulse expands as an elastic deformation wave over the entire metal structure of the crane. The article obtained the solutions that allow to determine the deflection of the crane rail and the dynamic factor when the wheel passes the joint of the rails.

The work [8] proposes a multimass dynamic model that takes into account the features and geometric parameters of the crane bridge and the position of the truck. It is used to study the dynamic forces and loads arising in the metal structure of the crane bridge and the lifting mechanism when the crane wheel passes the rail joint. However, the model does not account for rigidity of the crane route. The model diagram is presented in Fig. 1.

Using a dynamic model, as a result of theoretical studies and a numerical experiment to determine the shock loads during the movement of the overhead crane along the rail track, the following data were obtained: the dynamic factor for the position of the trolley in the middle of the run is 1.525 , for the position of the trolley at a quarter of a run is 2.425 , and for the extreme position of the trolley -3.29 [8].

The movement of cranes and the forces arising in the horizontal plane from the irregularities of the rail tracks were studied in the works $[9,10]$.

Unsolved aspects of the problem. The previously obtained results of theoretical studies do not take into account all the peculiarities of the overhead crane movement over the joint of the rail track because during the dynamic model construction, some assumptions were introduced to simplify the calculation. Therefore, to determine the adequacy of the dynam-

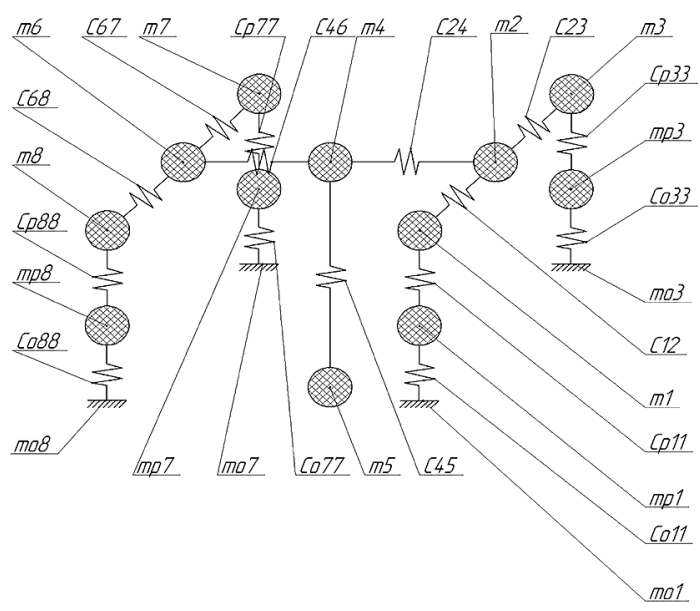

Fig. 1. Multimass dynamic model of the overhead crane ic model of the overhead crane, a task arose to conduct experimental studies.

The purpose of the work is to determine the dynamic factor in the crane end beams when it passes joints and irregularities of the crane rail track using a full-scale experiment.

Results. Although the full-scale experiment is associated with certain difficulties, after analyzing some methods of experimental research [9], it was decided to perform an experiment on a full-scale overhead crane.

Experimental studies were performed on an overhead twobeam crane with the capacity of 10 tons, with the run of $17.5 \mathrm{~m}$ (Fig. 2). This crane is operated in mechanical workshop No. 2 at Kharkiv Machine-Building Plant "Svitlo shakhtaria". To provide an estimate of the loads suffered by the metal structure of the crane, the electric strain measurement method was chosen using a direct bridge circuit (Fig. 3). To increase the sensitivity, two paper strain gages with a $150 \mathrm{~mm}$ base and $150 \mathrm{Ohm}$ resistance were installed in the bridge circuit.

The bridge circuit was powered by a $10 \mathrm{~V}$ DC power supply unit. An amplifier with a constant gain of 100 was used to amplify the bridge signal. Afterwards, the signal was recorded directly through the ADC of the computer sound card using Power Graph 2.1. The layout of strain gauges on the end beam of the overhead crane is shown in Figs. 4 and 5. This chart makes it was possible to measure the bending moment in $\mathrm{A}-\mathrm{A}$ section, where the strain gauges were attached. Moreover, knowing the geometric parameters of the beam cross-section enables estimation of the reaction force on the wheel support.

The bending moment in AA cross-section, based on the experimental diagram, can be calculated by the following formula

$$
M_{A-A}=F_{R} \cdot l,
$$

where $F_{R}$ is the reaction force on the wheel support; $l=0.45 \mathrm{~m}$ is the distance between the line of the force effect and the cross-section where the bending moment $M_{A-A}$ is measured (Fig. 4).

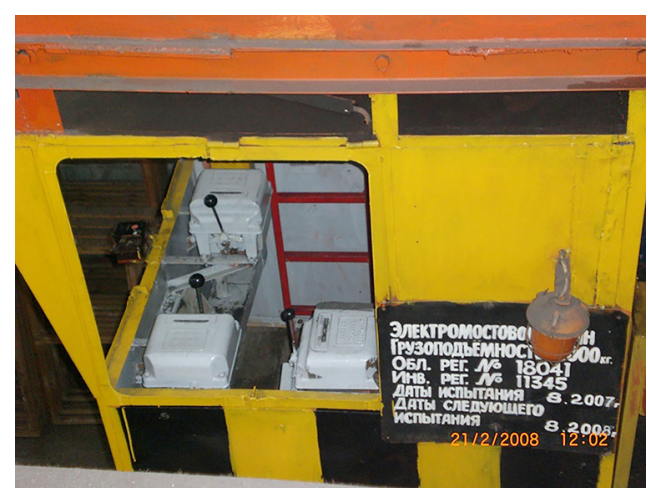

Fig. 2. Crane cabin with a sign plate

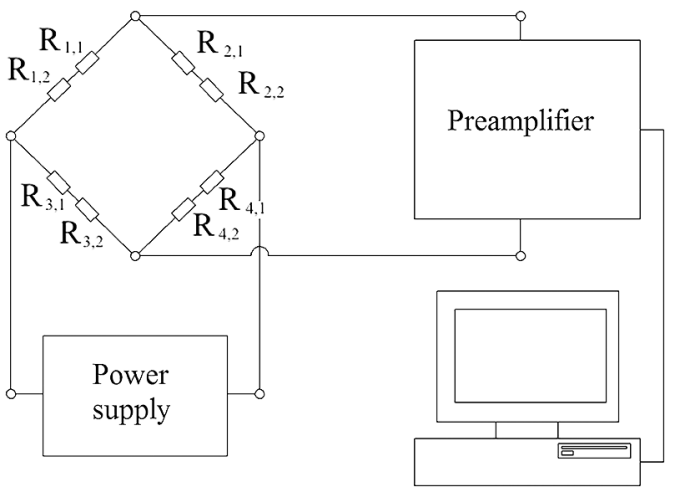

Fig. 3. Strain gauge connection circuit 


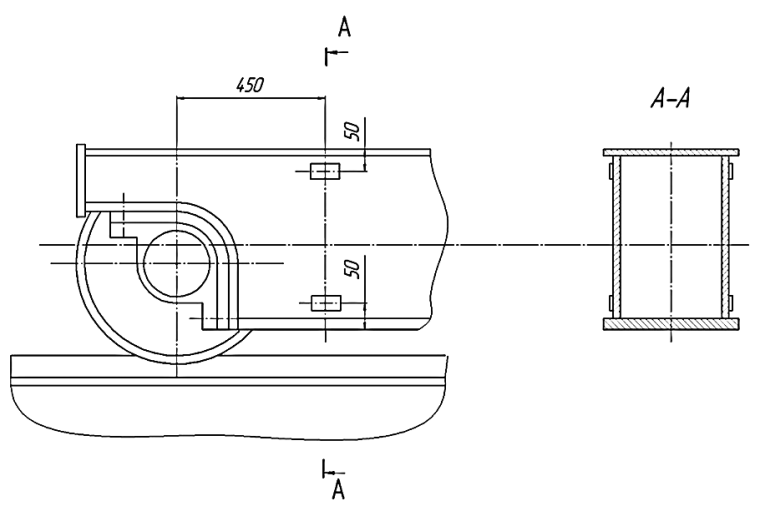

Fig. 4. Installation diagram of strain gauges on crane end beam

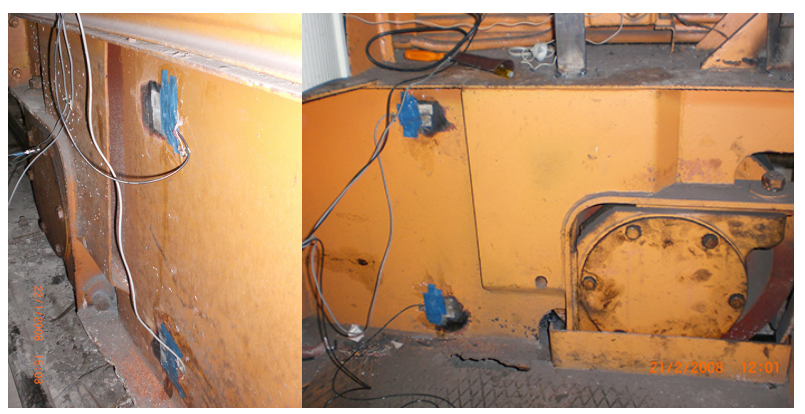

Fig. 5. Installation of strain gauges on the crane end beam

Therefore, knowing $F_{R}$, it is possible to determine the bending moment in AA section. The $F_{R}$ value is easy to find from the calculation diagram of the crane and determined support reactions.

The direct method was used to calibrate the strain gauge system, which means performing calibration directly on the structure where experimental studies will take place in the future. One of the most important conditions for such calibration is the condition of availability of data that will be recorded during experimental studies. In this case, for calibration purposes, the values of the bending moment and the force on the crane bridge support can be calculated with a high degree of accuracy. When calibrating the strain gauge system, the crane trolley was installed in the center of the crane run, so, the reaction forces on the supports are distributed evenly. Based on the calculation diagram (Fig. 6), they can be determined by the following formula

$$
F_{R 1}=F_{R 2}=F_{R 3}=F_{R 4}=\frac{P_{c r}+P_{c a}}{4},
$$

where $F_{R 1}, F_{R 2}, F_{R 3}, F_{R 4}$ are reactions of crane bridge supports which will equal each other only in case of the trolley installation in the middle of the crane run; $P_{c r}, P_{c a}$ are forces from the weight of the crane and cargo, respectively.

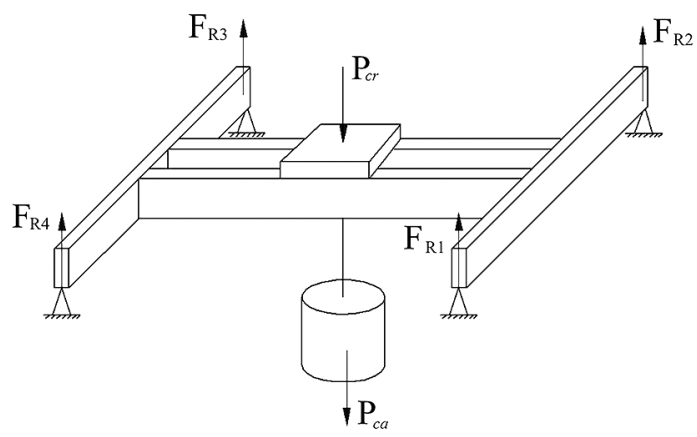

Fig. 6. Calculation diagram for the overhead crane for strain gauge calibration

The total weight of the crane is 12.4 tons. The strain gauge calibration was carried out with cargos of $3,4,5.5$ and 6.5 tons. The calibration data are shown in Table 1. Graphs of calibration values registration are shown in Fig. 7.

The dependency ratio between electric voltage $U$ and bending moment $M_{A-A}$ in the cross-section of the end beam, where the sensors are installed (Fig. 6), is calculated by the formula

$$
K_{M}=\frac{M_{A-A}}{U} .
$$

The dependency ratio between the reaction force on the support and the voltage of the strain gauge is determined by the equations (1) and (2) as follows

$$
K_{F}=\frac{K_{M}}{l} .
$$

The average ratios obtained through calibration, equal respectively $\quad K_{M}=13.24 \frac{\mathrm{kN} \cdot \mathrm{m}}{\mathrm{V}} ; \quad K_{F}=29.423 \frac{\mathrm{kN}}{\mathrm{V}}$. Afterwards, they were used to analyze the results obtained during the crane movement along the rail track.

Measurements were recorded after the crane passes the rail joint (Fig. 8). The gap between the rails was $6.3 \mathrm{~mm}$, and the difference in the levels was $3.1 \mathrm{~mm}$. The strain gauge voltages were registered when the crane wheel hit the outstanding rail (Fig. 10).

\begin{tabular}{|c|c|c|c|c|c|}
\hline 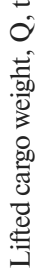 & 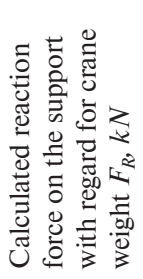 & 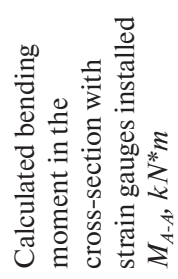 & 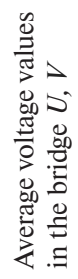 & 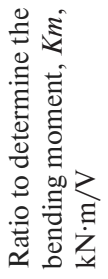 & 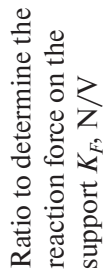 \\
\hline 3 & 33.343 & 15.004 & 1.133 & 13.243 & 29.429 \\
\hline 4 & 40.207 & 18.093 & 1.367 & 13.236 & 29.413 \\
\hline 5.5 & 43.885 & 19.748 & 1.492 & 13.236 & 29.414 \\
\hline 6.5 & 46.363 & 20.863 & 1.575 & 13.246 & 29.437 \\
\hline
\end{tabular}

Table 1

Main data during strain gauge calibration
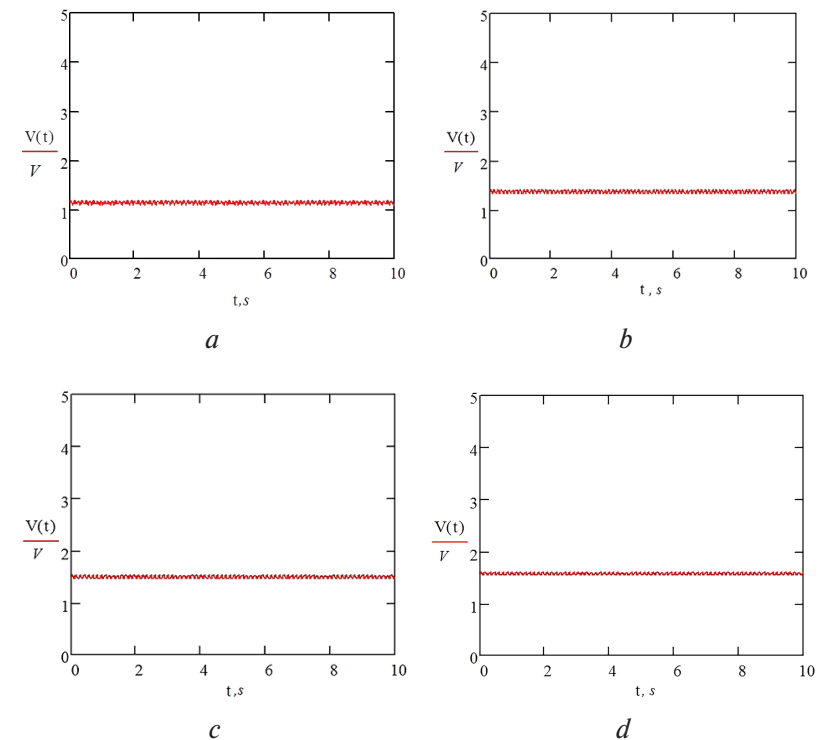

Fig. 7. Graphs of registration of strain gauge calibration values: $a-$ load $Q=3 t ; b-$ load $Q=4 t ; c-$ load $Q=5.5 t ; d-$ load $Q=6.5 t$ 


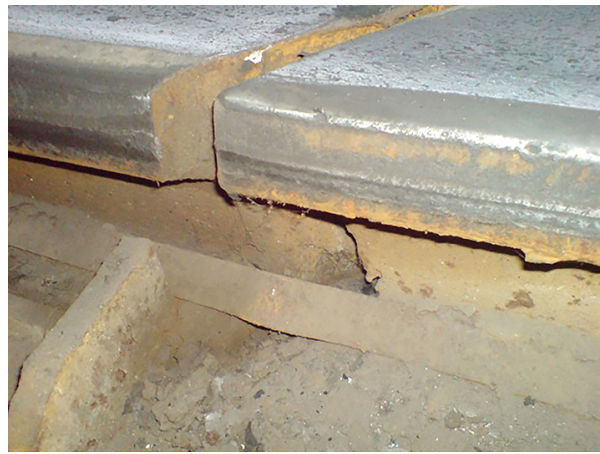

Fig. 8. Rail joint passing which is recorded

The crane was loaded with a 10 ton cargo. To increase the rigidity of the cargo suspension, it was raised to the maximum height so that the total length of the hoist was $2 \mathrm{~m}$. During the measurements, the position of the trolley was changed. In the first case, the trolley was installed in the middle of the crane run (Fig. 9). In the second case, the trolley was installed at a quarter of a crane run from the end beam with the strain gauge installed (Fig. 10). In the third case, the trolley was installed in

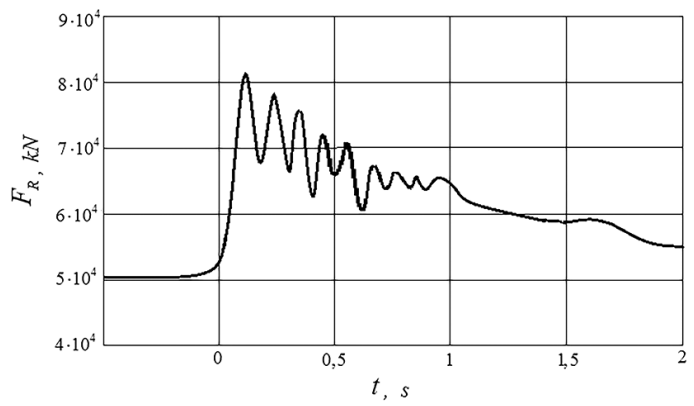

Fig. 9. Diagram of change in efforts with the trolley position in the middle of the run at $8.5 \mathrm{~m}$ from the end beam

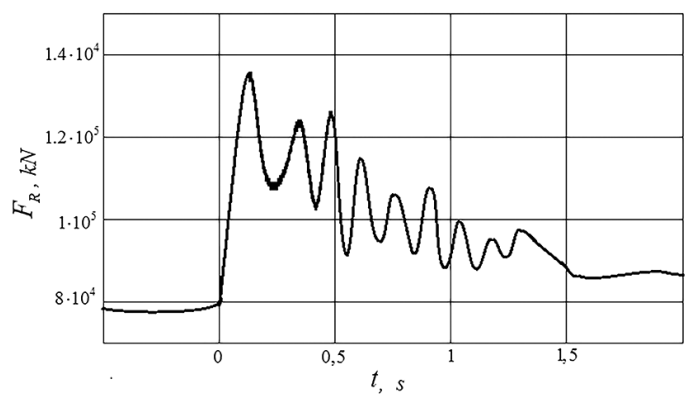

Fig. 10. Diagram of change in efforts with the trolley position at $4.25 \mathrm{~m}$ from the end beam

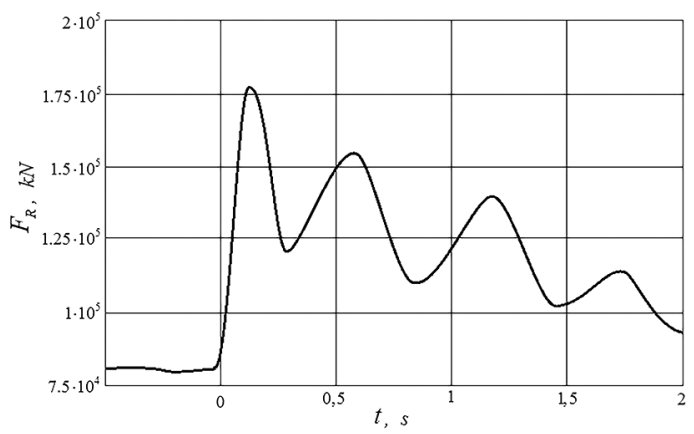

Fig. 11. Diagram of change in efforts with the trolley position at $1.7 \mathrm{~m}$ from the end beam its extreme position at $1.7 \mathrm{~m}$ from the crane end beam (Fig. 11). Figs. 9-11 show the processed diagrams, the specified time in seconds and the efforts in kilonewtons.

The static load experienced by the crane end beam was measured in all the three cases. Taking into account the proportion factor, the following data were obtained

$F_{R 1}=5.621 \cdot 10^{4} \mathrm{~N}-$ for case 1 ;

$F_{R 2}=6.863 \cdot 10^{4} \mathrm{~N}-$ for case $2 ;$

$F_{R 3}=7.686 \cdot 10^{4} \mathrm{~N}-$ for case 3 .

When analyzing the diagrams of change in the force on the crane support, the maximum dynamic force was calculated for each position of the trolley.

They constituted

$F_{R 1 \max }=8.652 \cdot 10^{4} \mathrm{~N}-$ for case 1 ;

$F_{R 2 \max }=1.381 \cdot 10^{5} \mathrm{~N}-$ for case 2 ;

$F_{R 3 \max }=1.873 \cdot 10^{5} \mathrm{~N}$ - for case 3 .

Accordingly, the dynamic factors calculated as ratios between the maximum dynamic force and the static one were as follows

$K_{d 1}=1.54-$ for case 1 ;

$K_{d 1}=2.46-$ for case 2 ;

$K_{d 1}=2.46-$ for case 3 .

Fig. 9. Diagram of change in efforts with the trolley position in the middle of the run at $8.5 \mathrm{~m}$ from the end beam

Conclusions.

1. As a result of the experiment, the dynamic factor on the end beam of the overhead crane was determined during its passing of the rail joint, and the data of theoretical studies were confirmed, which proves the equivalence of the dynamic model built.

2. The experimental data confirm the theoretical conclusions that determining the load in the crane metal structures from the impact of the wheels on the joint of the rails requires a dynamic factor taking into account the trolley position. If the trolley position cannot be determined due to varied crane movements in the production cycle, the maximum dynamic factor should be taken.

3. The experiment results established that the dynamic factor acquired the following values: 1.54 (when the trolley was in the middle of the bridge), 2.46 (when the trolley was at a distance of 0.25 of the crane run from the end beam), and 3.33 (when the trolley was in its extreme position), i.e. the trolley position at a distance of 0.25 of the crane run from the end beam corresponded to the dynamic factor of $74 \%$, and when the trolley position was in the middle of the bridge $-46 \%$ of the dynamic factor in case of the trolley being in its extreme position. The obtained data will enable more precise calculation of the crane bridge metal structure during its design, as well as during the repairs of the main and end beams.

4. Analysis of the experimental data showed that the dynamic shock is short-lived and vibration damping in the crane beams is complete within 2 seconds.

\section{References.}

1. Haniszewski, T. (2017). Modeling the dynamics of cargo lifting process by overhead crane for dynamic overload factor estimation. Journal of vibroengineering, 19(1), 75-86. https:// doi.org/10.21595/ jve.2016.17310.

2. Slepuzhnikov, E. D. (2015). Determination of dynamic loads when moving a truck crane bridge crane. Mashynobuduvannia, (16), 34-37.

3. Romacevych, Y., Loveikin, V., \& Stekhno, O. (2019). Closed-loop optimal control of a "trolley - payload" system. UPB Scientific Bulletin, Series D: Mechanical Engineering, 81(2), 5-12.

4. Franchuk, V.P., Ziborov, K.A., Krivda, V.V., \& Fedoriachenko, S. O., 2017. On wheel rolling along the rail regime with longitudinal load. Naukovyi Visnyk Natsionalnoho Hirnychoho Universytetu, (3), 62-67.

5. Markine, V., Mashal, A., \& Ren, M. (2018). Effect of wheel-rail interface parameters on contact stability in explicit 
finite element analysis. Proceedings of the Institution of Mechanical Engineers, Part F: Journal of Rail and Rapid Transit, 232(6), 1879-1894. https://doi.org/10.1177/0954409718754941.

6. Fidrovska, N., \& Perevoznyk, I. (2017). Dynamic loadings, which occur when the running wheel passes over joint of rail. Engineering: collection of scientific works. Ukrainian Engineering Pedagogical Academy, (20), 67-70.

7. Fidrovska, N., \& Perevoznyk, I. (2018). Impact loading at motion of bridge crane. Engineering: collection of scientific works. Ukrainian Engineering Pedagogical Academy, (21), 43-45.

8. Chernyshenko, O., Krasnokutska, T., \& Fesenko, H. (2011). Shock loads when the crane moves along the rail track. Bulletin of the National Technical University "KhPI" collection of scientific works, (54), 30-40.

9. Musilek, J. (2019). Dynamical Model for Determination of Horizontal Forces on Crane Runway during Motion of the Crane. IOP Conference Series: Materials Science and Engineering, (603, 052076). https://doi.org/10.1088/1757899X/603/5/052076.

10. Musilek, J. (2019). Horizontal Forces on Crane Runway Caused by Skewing of the Crane. IOP Conference Series: $M a$ terials Science and Engineering, (471, 052001). https://doi. org/10.1088/1757-899X/471/5/052001.

\section{Експериментальні дослідження руху мостового крана через стик рейкової колії}

Н. М. Фідровська ${ }^{1}$, О. В. Чернишенко ${ }^{2}$, І. А. Перевозник ${ }^{3}$ 1 - Харківський національний автомобільно-дорожній університет, м. Харків, Україна

2 - Українська інженерно-педагогічна академія, м. Харків, Україна, e-mail: chernishen.alex@gmail.com

3 - Харківський державний автомобільно-дорожній коледж, м. Харків, Україна

Мета. Підтвердження теоретичних висновків про те, що при визначенні навантаження від удару коліс о стик рейок у металоконструкції мостових кранів, які використовуються в технологічних процесах гірничо-збагачувальних фабрик і комбінатів та пересуваються рейковими коліями, необхідно приймати коефіцієнт динамічності з урахуванням положення візка.

Методика. Для надання оцінки навантаженням, що зазнає металоконструкція крана, було вибрано метод електро-тензометрування з використанням прямої мостової схеми. Для тарування тензометричної системи був використаний прямий метод, за якого тарування виконується безпосередньо на конструкції, на якій у подальшому будуть відбуватись експериментальні дослідження.

Результати. Було встановлено, що динамічний коефіцієнт у металоконструкції мостового крана при проходженні останнім рейкових стиків набуває таких значень: 1,54 (при знаходженні візка посередині мосту); 2,46 (при знаходженні візка на відстані 0,25 прогону крана від кінцевої балки); 3,33 (при знаходженні візка у крайньому положенні). Тобто, при знаходженні візка на відстані 0,25 прогону крана від кінцевої балки, динамічний коефіцієнт складає $74 \%$, а при знаходженні візка посередині мосту - $46 \%$ від коефіцієнту динамічності в разі знаходження візка у своєму крайньому положенні.

Наукова новизна. Полягає в тому, що вперше були експериментально підтверджені результати, отримані при теоретичних дослідженнях руху мостового крана через стики рейкової колії з урахуванням положення візка крана, що призводить до зміни жорсткості головної балки на ділянці від візка до кінцевої балки.

Практична значимість. Отримані результати надають можливість виконувати розрахунки металоконструкції мосту крана при проектуванні й ремонті головних і кінцевих балок з урахуванням значення коефіцієнту динамічності, що дозволяє підвищити надійність і довговічність металоконструкції крана в цілому.

Ключові слова: мостовий кран, стик рейкової колії, коефіцієнт динамічності, коливання в балках мостового крана, динамічний удар

\section{Экспериментальные исследования движения мостового крана через стык рельсового пути}

\author{
Н. Н. Фидровская ${ }^{1}$, А. В. Чернышенко ${ }^{2}$, \\ И. А. Перевозник ${ }^{3}$
}

1 - Харьковский национальный автомобильно-дорожный университет, г. Харьков, Украина

2 - Украинская инженерно-педагогическая академия, г. Харьков, Украина, e-mail: chernishen.alex@gmail.com

3 - Харьковский государственный автомобильно-дорожный колледж, г. Харьков, Украина

Цель. Подтверждение теоретических выводов о том, что при определении нагрузок от удара колес о стык рельсов в металлоконструкции мостовых кранов, использующихся в технологических процессах горнообогатительных фабрик и комбинатов и передвигающихся по рельсовым путям, необходимо принимать коэффициент динамичности с учетом положения тележки.

Методика. Для оценки нагрузок, которые воспринимает металлоконструкция крана, был выбран метод электротензометрирования с использованием прямой мостовой схемы. Для тарирования тензометрической системы был использован прямой метод, при котором тарирование выполняется непосредственно на конструкции, на которой в дальнейшем будут проводиться экспериментальные исследования.

Результаты. Было установлено, что динамический коэффициент в металлоконструкции мостового крана при прохождении последним рельсовых стыков принимает такие значения: 1,54 (при нахождении тележки посредине моста); 2,46 (при нахождении тележки на расстоянии 0,25 пролета крана от концевой балки); 3,33 (при нахождении тележки в крайнем положении). То есть, при нахождении тележки на расстоянии 0,25 пролета крана от концевой балки, динамический коэффициент составляет $74 \%$, а при нахождении тележки посредине моста - $46 \%$ от коэффициента динамичности в случае нахождения тележки в своем крайнем положении.

Научная новизна. Состоит в том, что впервые экспериментально подтверждены результаты, полученные при теоретических исследованиях движения мостового крана через стыки рельсового пути с учетом положения тележки крана, что приводит к изменению жесткости главной балки на участке от тележки до концевой балки.

Практическая значимость. Полученные результаты дают возможность выполнять расчеты металлоконструкции моста крана при проектировании и ремонте главных и концевых балок с учетом значения коэффициента динамичности, что позволяет повысить надежность и долговечность металлоконструкции крана в целом.

Ключевые слова: мостовой кран, стык рельсового пути, коэффициент динамичности, колебания в балках мостового крана, динамический удар

Recommended for publication by S.V.Raksha, Doctor of Technical Sciences. The manuscript was submitted 22.10.19. 